\title{
Increased incidence of faecal coliforms with in vitro adhesive and invasive properties in patients with ulcerative colitis
}

\author{
R J DICKINSON,*'S A VARIAN, A T R AXON, AND E M COOKE \\ From the Gastroenterology Unit, The General Infirmary at Leeds, and the Department of Microbiology, \\ University of Leeds, Leeds
}

SUMMARY Faecal samples were collected from 23 patients with active ulcerative colitis, 15 patients with established ulcerative colitis in remission, 20 patients with active colitis of cause other than ulcerative colitis, and 20 normal control subjects. Ten coliform colonies were randomly selected from the faecal sample cultures and serotyped before the testing of each different serotype from each sample for adhesive or invasive properties on HeLa cell monolayers. In the patients with both active ulcerative colitis and ulcerative colitis in remission and those with other types of colitis one serotype tended to dominate the faecal coliform flora. In normal controls more variety was encountered. Thirty-five per cent of the patients with active ulcerative colitis and $27 \%$ of the patients with ulcerative colitis in remission had at least one adhesive or invasive faecal coliform as compared with $5 \%$ of the patients with other types of colitis and $5 \%$ of the normal controls. These findings are significant $(\mathrm{P}<0.05)$ and may have aetiological and therapeutic significance.

The aetiology of ulcerative colitis remains unknown. The characteristic inflammation in the disorder usually affects varying extents of the large intestinal mucosa, which is the area of the intestine most intimately associated with the aerobic flora. ${ }^{1}$ In spite of this fact, there has been little published work on the qualitative aspects of the aerobic faecal flora apart from that of Cooke (1968) who showed differences in the faecal $E$. coli of patients with ulcerative colitis compared with controls in respect to production of haemolysin and necrotoxin and the ability to dilate rabbit ileal loops. ${ }^{2}$

The possibility that the coliform flora is involved in the aetiology of ulcerative colitis is increased by the observation that $E$. coli may act as a primary pathogen in the bowel ${ }^{13}$ as may other coliforms in some situations. ${ }^{45}$ Furthermore, there is much anecdotal evidence relating the onset of ulcerative colitis and its exacerbations to attacks of infective diarrhoea, a proportion of which may be caused by pathogenic coliforms. ${ }^{135}$

In this study we have investigated the possibility that there are qualitative differences in the faecal

*Address for correspondence: Dr R J Dickinson, Department of Medicine, Addenbrooke's Hospital, Hills Road, Cambridge, England. Received for publication 13 May 1980 coliforms of patients with ulcerative colitis. In particular we have investigated faecal coliforms for adhesive and invasive properties, both of which appear to relate to the ability of enteric pathogens to produce disease. ${ }^{6}{ }^{7}$ For comparison we have studied the coliforms of patients with colitis thought to be due to disease other than ulcerative colitis and normal controls.

\section{Methods}

PATIENTS

Faecal samples were obtained from the following groups of patients.

\section{Active ulcerative colitis}

Twenty-three patients with active proctitis or proctocolitis all of whom had symptoms of their disease. Twenty patients were in hospital and in all cases the diagnosis was made according to accepted criteria. $^{8}$

\section{Quiescent ulcerative colitis}

Fifteen out-patients with established ulcerative colitis in clinical remission. One of these patients had been studied three months previously in group 1 . 
Other active colitis

Twenty patients with active colitis thought to be due to conditions other than ulcerative colitis. In all cases the diagnosis was based on the clinical history and findings, taken in conjunction with the results of routine bacteriological, radiological, and histological investigations. Five thad Crohn's disease of the colon, six antibiotic related colitis or pseudomembraneous colitis and three infective colitis with recognised pathogens. The other six all had a short history of diarrhoea of sudden onset, and, although no intestinal pathogens were identified, an infective cause for the colitis was considered most probable on clinical and investigational grounds. ${ }^{9}$ No patient in this group had the rectal findings of ulcerative colitis. $^{8}$

\section{Normal controls}

Twenty adults who had neither been in hospital nor received antibiotics for at least one year.

\section{Procedure}

Faecal samples were obtained as soon as possible after the presentation of the patient to hospital. The samples were inoculated on to blood agar and incubated overnight at $37^{\circ} \mathrm{C}$.

A typical coliform colony was then randomly selected and identified as E.coli or Klebsiella species as previously. $^{210}$ This colony and nine others similarly selected were then stored on Dorset Egg medium at room temperature in the dark until use.

The E.coli and klebsiellas studied were from the first faecal sample obtained, except in the case of a patient with bacteriological evidence of staphylococcal enterocolitis who had no faecal coliforms until five days after admission.

\section{SEROTYPING}

E.coli were 0-serotyped and klebsiellas capsular typed as previously, ${ }^{1011}$ using 1560 antisera and 77 capsular antisera respectively. Every colony from each sample was serotyped and then at least one representative of each different serotype from each faecal sample was tested for its ability to adhere to or invade HeLa cells in culture.

\section{HELA CELL STUDIES}

Adhesiveness and invasiveness were investigated on HeLa cell monolayers after the method of La Brec et al. (1964). ${ }^{\text {? }}$

HeLa Ohio cells were maintained in tissue culture in Minimum Essential Medium (Glasgow's modification of Eagle's medium). Immediately before use each $150 \mathrm{ml}$ of medium were enriched with $20 \mathrm{ml}$ tryptose phosphate broth, $20 \mathrm{ml}$ calf serum, $2 \mathrm{ml}$ glutamine solution (containing $29.2 \mathrm{mg}$ glutamine/ $\mathrm{ml}$ ), and $10 \mathrm{ml} \mathrm{3 \%}$ sodium bicarbonate. The stripping medium comprised $100 \mathrm{ml}$ phosphate buffered saline (PBS-pH 7.2) containing $2 \mathrm{ml} 1 \%$ versene, $0.5 \mathrm{ml}$ trypsin, and $3.5 \mathrm{ml} 3 \%$ sodium bicarbonate.

The test HeLa cells (approximately $10^{6}$ ) were transferred to plastic petri dishes containing glass coverslips and maintained in an atmosphere of $95 \%$ air $5 \% \mathrm{CO}_{2}$ at $37^{\circ} \mathrm{C}$ until nearly confluent. The cells were then infected with approximately $3.5 \times 10^{7}$ washed bacteria obtained from overnight incubation in nutrient broth. The petri dishes were reincubated at $37 \%$ in an atmosphere of $95 \%$ air, $5 \% \mathrm{CO}_{2}$, and coverslip samples were taken at three, five, and seven hours, and sometimes 10, 12, and 18 hours after infection. Before taking coverslip samples the petri dishes were emptied of culture medium and washed twice with Hank's balanced salt solution. Fresh medium was then added and the petri dishes reincubated. The coverslip samples were washed in PBS, fixed in three parts methanol: one part acetic acid, and stained with dilute Giemsa at pH 7 before examination under the light microscope.

Non-adhesive and non-invasive strains were usually not evident on any of the coverslip preparations. Scattered bacteria or bacterial clumps unrelated to the cell membranes were also regarded as negative. Adhesive strains had attached to the cells within three hours, usually in a patchy distribution. Adhesion increased variably with further incubation but invasion of the monolayer and its consequent disruption did not occur, even if incubation was prolonged up to 12 hours after infection (Fig. 1). Invasive strains usually affected the entire monolayer in a pattern initially similar to that of the adhesive strains. After five hours' incubation bacteria could usually be seen within the cells and, by seven hours, disruption of the monolayer had invariably occurred (Fig. 2.).

All strains deemed adhesive or invasive were tested at least twice and categorisation was based on the agreement of two observers one of whom was unaware of the clinical diagnosis.

\section{Results}

The results of this study are summarised in Tables 1,2 , and 3 . In all but one patient, the 10 coliform colonies were identified as E.coli. In the exceptional case all the colonies were Klebsiella and these comprised three different serotypes.

It will be seen that the faecal samples from all the patients with active colitis of whatever cause and from those with quiescent ulcerative colitis yielded generally fewer serotypes than those from the normal controls. Furthermore, differences in serotype among the 10 colonies from the patients with 


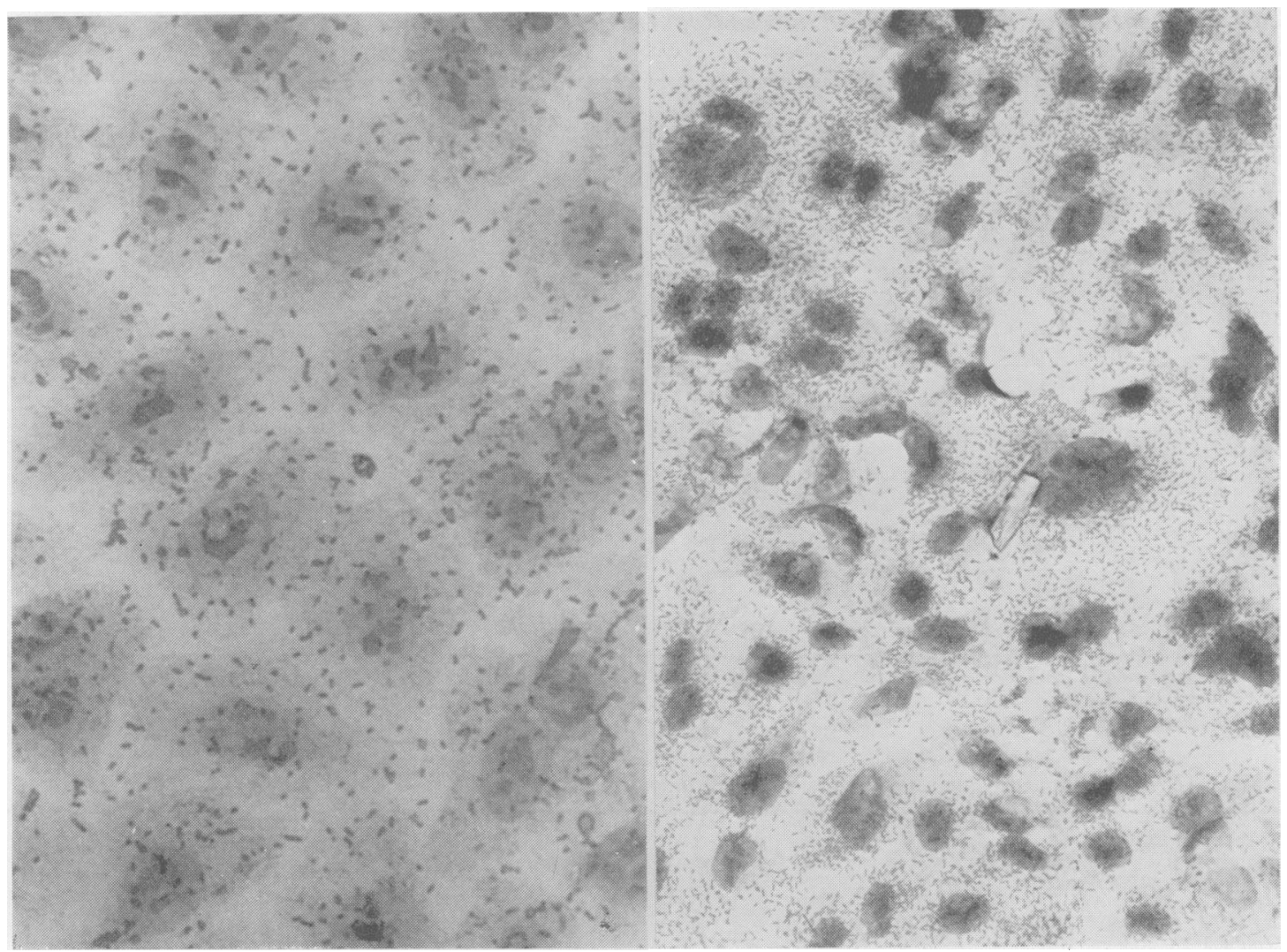

Fig. 1 Adhesive strain, seven hour sample. There is no monolayer disruption. Giemsa, $\times 2000$.

active colitis and quiescent ulcerative colitis were often from typable to rough or non-typable and possibly therefore variants of the same strain. ${ }^{12}$ This occurred less frequently in the normal controls who yielded a wide variety of serotypes.

Adhesive or invasive serotypes were encountered at an increased frequency in the patients with active ulcerative colitis and quiescent ulcerative colitis when compared with the patients with other colitis or normal controls $(\mathrm{P}<0.05$ in both instances by Fisher's test). The adhesive or invasive strains were usually representative of the dominant sero-

Table 1 Details of diagnostic groups, number of serotypes isolated, and frequency of adhesive or invasive strains

\begin{tabular}{|c|c|c|c|c|c|c|}
\hline $\begin{array}{l}\text { Diagnostic } \\
\text { group }\end{array}$ & $\begin{array}{l}\text { No. of } \\
\text { patients }\end{array}$ & $\begin{array}{l}\text { No. of } \\
\text { serotypes } \\
\text { tested }\end{array}$ & $\begin{array}{l}\text { No. of } \\
\text { adhesive } \\
\text { serotypes }\end{array}$ & $\begin{array}{l}\text { No. of } \\
\text { invasive } \\
\text { serotypes }\end{array}$ & $\begin{array}{l}\text { Mean no. } \\
\text { serotypes } \\
\text { /sample }\end{array}$ & $\begin{array}{l}\% \text { patients with } \\
\text { adhesive or invasive } \\
\text { serotypes }\end{array}$ \\
\hline Active UC & 23 & 33 & 6* & 3 & 1.4 & $35^{*}$ \\
\hline Quiescent UC & 15 & 20 & 4 & 0 & $1 \cdot 3$ & 27 \\
\hline Other colitis & 20 & 25 & 1 & 0 & $1 \cdot 3$ & 5 \\
\hline Normal control & 20 & 37 & 0 & 1 & 1.9 & 5 \\
\hline
\end{tabular}

*One patient had two adhesive serotypes in one sample.

type, although one patient with active ulcerative colitis had two adhesive strains one of which, E.coli 0153 , was represented by a single colony.

\section{Discussion}

In any study of the faecal flora there are inevitable questions concerning the validity of results obtained at bacteriology. The bacterial population of the flora is so large that the sampling methods used must be reliable before any deductions can be made relating laboratory findings to the pathogenesis of 
Table 2 Detail of $O$ serotype of E.coli and capsular type of species Klebsiella in each group of patients studied (dominant serotype given first)

\begin{tabular}{llll}
\hline Active UC $(n=23)$ & Other colitis $(n=20)$ & Quiescent $U C(n=15)$ & Controls $(n=20)$ \\
\hline OR & ONT & OR & $015,016$. OR \\
019 & 053 & 01 & ONT, 049, 0157 \\
021 & 06 & 02 & 06,011 \\
OR & 075, ONT & OR & $016,02,09$ \\
$018 \mathrm{ab}$ & 06 & 086, ONT & 091,028 \\
019,08, ONT & OR, ONT & 04 & 081 \\
02,077 & 083 & OR & 08,051 \\
08 & 0153 & 01 & 022 \\
0102 & 07 & 01 & 075,065 \\
063,0153 & ONT & 01, OR & 059 \\
01 & $018 \mathrm{ab}$ & $02, \mathrm{ONT}$ & 0155 \\
OR & 02 & ONT & 048 \\
087 & 0111,06 & 06 & ONT, 081, OR \\
0153, OR & 075 & $0146,018 \mathrm{ab}$, ONT & $018 \mathrm{ab}, 021$ \\
OR, ONT & 075 & 0153 & ONT \\
OR & $075,018 \mathrm{ab}$ & & 015 \\
08 & ONT & & $018 \mathrm{ab}, 09$ \\
02 & 05 & & 081,021 \\
020, OR & $018 \mathrm{ab}$ & & 088,0126 \\
01 & 04,08 & & 021,062 \\
023, ONT & & & \\
K45, K2, K58* & & & \\
ONT & & & \\
\hline
\end{tabular}

OR: Rough strain.

ONT: Non-typable strain.

* Klebsiella capsular type.

Table 3 Details of adhesive and invasive strains in each diagnostic group

\begin{tabular}{|c|c|c|c|}
\hline Active UC $(n=8)$ & Quiescent UC $(n=24)$ & Other colitis $(n=1)$ & Controls $(n=1)$ \\
\hline 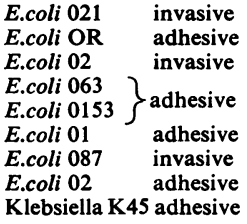 & $\begin{array}{l}\text { E.coli } \text { OR adhesive } \\
\text { E.coli } 01 \text { adhesive } \\
\text { E.coli } 0146 \text { adhesive } \\
\text { E.coll } 0153 \text { adhesive }\end{array}$ & E.coli $018 \mathrm{ab}$ adhesive & E.coli 028 invasive \\
\hline
\end{tabular}

disease. It is recognised that the faecal coliform flora in health may comprise a variety of serotypes, some of which are represented in small measure, and that the greater number of coliform colonies tested in each faecal sample, the greater the theoretical yield of serotypes. ${ }^{13}$ In order to identify the dominant serotype in each sample, we have chosen to select 10 colonies, as there is good evidence from a number of previous studies ${ }^{13-15}$ that this method will reveal the dominant serotype of that sample. There is also evidence from a colonoscopic study ${ }^{16}$ that serotypes that dominate the faecal sample also dominate the entire colonic flora and these observations suggest that our sampling methods are valid. In this study we have usually restricted ourselves to studying one faecal sample per patient. While it could be argued that the results we have obtained might be due to chance shedding of faecal pathogens, ${ }^{17}$ this would seem unlikely, especially as second samples obtained from five patients soon after admission to hospital either showed no change in 0-serotype of the colonies tested, or, if the original coliforms were nontypable, no change in antibiotic sensitivity in similarly non-typable strains.

In order to facilitate testing for other properties, we have assumed that each coliform colony with the same 0-serotype from the same patient had similar properties with regard to adhesiveness or invasiveness. This assumption might be invalid if adhesiveness and invasiveness are both plasmidmediated, or if different bacterial strains with the same serotype can coexist in the same faecal sample. As all samples were treated similarly, however, it is unlikely that the results we have obtained can be accounted for thus and, in any event, while there is evidence to suggest that there is heterogeneity of properties among E.coli colonies with the same 0-type in the faeces of normal persons, ${ }^{14}$ the coliforms in disease conditions are 
probably more homogeneous (Varian and Cooke, unpublished observations), as is shown by our finding that one serotype tended to dominate the flora in patients with active and quiescent colitis, but not in normal persons.

We have used the HeLa cells model of LaBrec et al. (1964) to assess adhesiveness and invasiveness. ${ }^{7}$ This method has been criticised because of the difficulties that may be encountered in differentiating between adhesion and invasion. ${ }^{18}$ We did not find this distinction difficult, as strains were deemed invasive only if they produced monolayer disruption within seven hours of infection. ${ }^{7}$ Adhesive strains did not cause disruption even if incubation was prolonged to 12 hours but overnight incubation was misleading, as monolayer disruption, secondary to the effects of bacterial multiplication on the culture medium, usually led to non-specific bacterial adhesion $^{19}$ and an appearance similar to that of the late effects of an invasive strain. Thus we consider the technique useful but only if the monolayers are inspected frequently and assessment of adhesion or invasion is based on a study of evolving change.

Adhesion by bacterial pathogens to host cells is well recognised and appears to be an essential step in the pathogenesis of some diseases. ${ }^{20}$ Adhesion to the intestine may facilitate colonisation by toxinproducing bacteria ${ }^{21}$ or even be a primary pathogenic property. ${ }^{22}$ The precise significance of the adhesion we have found is uncertain, as only one of the strains, E.colis 063, is a known enterotoxigenic serotype, ${ }^{23}$ but, while the mechanisms of E.coli diarrhoea remain incompletely understood, tests for adhesiveness are useful in determining potential pathogenicity. ${ }^{618}$ The adhesion by enteric pathogens to host cells has been best described in animals where a high degree of host-parasite specificity obtains. ${ }^{24}{ }^{25}$ Adhesion to HeLa cells clearly lacks this specificity but, in studies of urinary tract E.coli, the ability to adhere to HeLa cells was shown to correlate with the more specific ability to adhere to uroepithelial cells, although more strains adhered to the latter, ${ }^{26}$ and it might be that the use of cells more closely related to colonic epithelium would reveal an even greater incidence of adhesive strains in a similar patient population. The fetal colon assay of McNeish et al. ${ }^{6}$ would be of value in this respect, as might the recently described use of intestine 407 cells. ${ }^{27}$

The adhesive klebsiella is of interest. Although klebsiellas are not widely recognised as enteric pathogens, they have been described as such. ${ }^{45}$ Additional research is indicated into the role of klebsiellas in the pathogenesis of enteric disease.

The invasion of HeLa cells by enteric pathogens is recognised as being indicative of in vivo pathogeni- city. ${ }^{7}$ Hitherto, the invasive property has been attributed to a small number of E.coli 0-serotypes $(028,0112,0124,0136,0143,0144),{ }^{23}$ although studies to date have been largely confined to patients with infectious diarrhoea. Only one recognised invasive serotype, 028, was encountered in this study; the other invasive strains being 021,02 , and 087 respectively. Recent work on the pathogenicity of E.coli has, however, demonstrated that the relationship between pathogenic properties and 0 -serotype is inconstant ${ }^{18}{ }_{28}^{29}$ and the lack of correlation between 0 -serotype and pathogenicity makes it probable that additional investigation will reveal a greater variety of 0 -serotypes with which the invasive property can be associated..$^{30}$

In this study we have made two findings. Firstly, we have found that one E.coli-serotype tends to dominate the faecal flora of patients with both active colitis, of whatever cause, and quiescent ulcerative colitis. In some instances the dominant serotype may have been selected by a change of diet consequent upon admission to hospital, ${ }^{12}$ or by prior treatment with sulphasalazine or other antimicrobials. However, these possibilities are unlikely to account for the results we have obtained, as the majority of the patients studied had faecal samples taken within $\mathbf{4 8}$ hours of admission to hospital and, while the majority of the patients with quiescent ulcerative colitis (13 out of 15) were taking antimicrobials at the time of study, only 12 out of 43 of the patients with active colitis were doing so. Secondly, we have found an increased incidence of adhesive or invasive serotypes in the patients with active and quiescent ulcerative colitis when compared with the other groups studied. This finding might be explicable on the basis of enhanced survival of such coliforms in patients with colonic disease, although their relative infrequency in the patients with other colitis would be unexpected if this were the case. Alternatively, it may provide additional evidence for an association between enteric infection and ulcerative colitis. The significance of positive faecal cultures in patients with ulcerative colitis is unclear and findings for salmonella and shigella organisms, similar to those we have made for coliforms, have been interpreted both as evidence for an increased tendency to pathogen carriage ${ }^{31}$ and for a primary aetological relationship ${ }^{32}$ respectively. Additional work is indicated, especially as a report of raised serum antibody levels to the traditional enteroinvasive E.coli serotypes in patients with ulcerative colitis supports the possibility that pathogenic coliforms are involved in the pathogenesis of this disease. ${ }^{33}$ If this is so, then a rational basis would be provided for attempts to treat the disease by alteration of the aerobic faecal flora. 
$R \mathrm{~J} \mathrm{D}$ is in receipt of research funds from the Leeds General Infirmary Special Trustees. S A V was in receipt of a MRC studentship at the time of this study. We would like to thank those physicians and surgeons of Leeds who allowed us to study patients under their care. We also wish to thank Dr A S Edmondson for typing the klebsiellas, Mr M Freeman for assistance with the tissue cultures, and Mrs C L Baxendale for typing the manuscript.

\section{References}

${ }^{1}$ Gorbach SL. Intestinal microflora. Gastroenterology 1971; 60: 1110-29.

${ }^{2}$ Cooke EM. Properties of strains of Escherichia coli isolated from the faeces of patients with ulcerative colitis, patients with acute diarrhoea and normal persons. J Path Bact 1968; 95: 101-13.

${ }^{3}$ Phillips I. Microbial infections and intoxications of the small intestine. In: Creamer $\mathrm{B}$, ed. The small intestine. London: Heinemann, 1974: 190-204.

${ }^{4}$ Klipstein FA, Holdeman LV, Corcino JJ, Moore WEC. Enterotoxigenic intestinal bacteria in tropical spruce. Ann Intern Med 1973; 79: 632-41.

${ }^{5}$ Guerrant RL, Moore RA, Kirschenfeld PM, Sande MA. Role of toxigenic and invasive bacteria in acute diarrhea of childhood. $N$ Engl J Med 1975; 293: 567-73.

${ }^{6}$ McNeish AS, Turner P, Fleming J, Evans N. Mucosal adherence of human enteropathogenic Escherichia coli. Lancet 1975; 2: 946-8.

${ }^{7}$ LaBrec EH, Schneider H, Magnani TJ, Formal SB. Epithelial cell penetration as an essential step in the pathogenesis of bacillary dysentery. J Bacteriol 1964; 88: 1503-18.

${ }^{8}$ Lennard-Jones JE, Ritchie JK, Zohrab WJ. Proctocolitis and Crohn's disease of the colon: a comparison of the clinical course. Gut 1976; 17:477-82.

${ }^{9}$ Dickinson RJ, Gilmour HM, McClelland DBL. Rectal biopsy in patients presenting to an infectious disease unit with diarrhoeal disease. Gut 1979; 20 : 141-8.

${ }^{10}$ Edmondson AS, Cooke EM. The development and assessment of a bacteriocin typing method for Klebsiella. J Hyg (Camb) 1979; 82: 207-23.

${ }^{11}$ Bettelheim KA, Taylor J. A study of Escherichia coli isolated from chronic urinary infection. $J$ Med Microbiol $1969 ; 2$ : 225-36.

${ }^{12}$ Bettelheim KA, Cooke EM, O'Farrell S, Shooter RA. The effect of diet on intestinal Escherichia coli. J Hyg (Camb) 1977; 79: 43-5.

${ }^{13}$ Vosti KL, Monto AS, Rantz LA. The importance of sample size in studies based upon the serologic classification of Escherichia coli. Proc Soc Exp Biol Med 1962; 111: 201-4.

${ }^{14}$ Lidin-Janson G, Kaijser B, Lincoln K, Olling S, Wedel $H$. The homogeneity of the faecal coliform flora of normal schoolgirls characterised by serological and biochemical properties. Med Microbiol Immunol 1978; 164: 247-53.

${ }^{15}$ Bettelheim KA, Faiers M, Shooter RA. Serotypes of Escherichia coli in normal stools. Lancet 1972; 2: 1224-6.

${ }^{16}$ Hartley CL, Neumann CS, Richmond MH. Adhesion of commensal bacteria to the large intestine wall in humans. Infect Immunol 1979; 23: 128-32.

${ }^{17}$ Pickering LK, Dupont HL, Evans DG, Evans DJ Jr., Olarte J. Isolation of enteric pathogens from asymptomatic students from the United States and Latin America. J Infect Dis. 1977; 135 : 1003-5.

${ }^{18}$ Evans N. Pathogenic mechanisms in bacterial diarrhoea. Clin Gastroenterol 1979; 8: 599-623.

${ }^{19} \mathrm{McNeish}$ AS, In: Acute diarrhoea in childhood. Elliott K, Knight J, eds. Amsterdam Elsevier. (Ciba Foundation Symposium) 42: 1976; 67.

${ }^{20}$ Smith H. Microbial surfaces in relation to pathogenecity. Bact Rev 1977; 41:475-500.

${ }^{21}$ Hohmann A, Wilson MR. Adherence of enteropathogenic Escherichia coli to intestinal epithelium in-vivo. Infect Immunol 1975; 12: 866-80.

${ }^{22}$ Ulshen MH, Rollo JL. Pathogenesis of Escherichia coli gastroenteritis in man-another mechanism. $N$ Engl J Med 1980; 302: 99-101.

${ }^{23}$ Ørskov I, Ørskov F, Jann B, Jann K. Serology, Chemistry and genetics of $\mathrm{O}$ and $\mathrm{K}$ antigens of Escherichia coli. Bact Rev 1977; 41: 669-710.

${ }^{24}$ Arbuckle JBR. The location of Escherichia coli in the pig intestine. J Med Microbiol 1970; 3: 333-40.

${ }^{25}$ Jones GW, Rutter JM. Role of the K88 antigen in the pathogenesis of neonatal diarrhea caused by Escherichia coli in piglets. Infect Immunol 1972; 6: 918-27.

${ }^{26}$ Varian SA, Cooke EM. Adhesive properties of Escherichia coli from urinary-tract infections. J Med Microbiol 1980; 13: 111-9.

${ }^{27}$ Hartley CL, Robbins CM, Richmond MH. Quantitative assessment of bacterial adhesion to eukaryotic cells of human origin. J Appl Bact 1978; 45: 91-7.

${ }^{28}$ Gangarosa EJ, Merson MH. Epidemiologic assessment of the relevance of the so-called enteropathogenic serogroups of Escherichia coli in diarrhea. $N$ Engl J Med 1977; 296: 1210-3.

${ }^{29}$ Goldschmidt MC, Dupont HL. Enteropathogenic Escherichia coli: lack of correlation of serotype with pathogenicity. J Infect Dis 1976; 133: 153-6.

${ }^{30}$ Toledo MRF, Reis MHL, Almada RG, Trabulsi LR. Invasive strain of Escherichia coli belonging to $\mathrm{O}$ group 29. J Clin Microbiol 1979; 9: 288-9.

${ }^{31}$ Lindeman RJ, Weinstein L, Levitan R, Patterson JF. Ulcerative colitis and intestinal salmonellosis. $A m J$ Med Sci 1967; 254: 855-61.

${ }^{32}$ Felsen J, Wolarsky W. Acute and chronic bacillary dysentery and chronic ulcerative colitis. J Am Med AsS 1953; 153: 1069-72.

${ }^{33}$ Tabaqchali S, O'Donoghue DP, Bettelheim KA. Escherichia coli antibodies in patients with inflammatory bowel disease. Gut 1978; 19: 108-113. 